10-1991

\title{
Genetic Variation in the Timing of Gonadal Maturation and Spawning of the Eastern Oyster, Crassostrea virginica (Gmelin)
}

Bruce J. Barber

Virginia Institute of Marine Science

Susan E. Ford

Robert N. Wargo

Follow this and additional works at: https://scholarworks.wm.edu/vimsarticles

Part of the Aquaculture and Fisheries Commons, and the Marine Biology Commons

\section{Recommended Citation}

Barber, Bruce J.; Ford, Susan E.; and Wargo, Robert N., "Genetic Variation in the Timing of Gonadal Maturation and Spawning of the Eastern Oyster, Crassostrea virginica (Gmelin)" (1991). VIMS Articles. 1695.

https://scholarworks.wm.edu/vimsarticles/1695

This Article is brought to you for free and open access by the Virginia Institute of Marine Science at W\&M ScholarWorks. It has been accepted for inclusion in VIMS Articles by an authorized administrator of W\&M ScholarWorks. For more information, please contact scholarworks@wm.edu. 


\title{
Genetic Variation in the Timing of Gonadal Maturation and Spawning of the Eastern Oyster, Crassostrea virginica (Gmelin)
}

\author{
BRUCE J. BARBER ${ }^{1}$, SUSAN E. FORD ${ }^{2}$, AND ROBERT N. WARGO ${ }^{2, *}$ \\ ${ }^{1}$ Virginia Institute of Marine Science, College of William and Mary, Gloucester Point, Virginia \\ 23062, and ${ }^{2}$ Shellfish Research Laboratory, Rutgers University, New Jersey Agricultural Experiment \\ Station, Institute of Marine and Coastal Sciences, Port Norris, New Jersey 08349
}

\begin{abstract}
The gonadal cycles of four groups of eastern oysters, Crassostrea virginica (Gmelin), including native stocks collected that year and inbred strains (reared in Delaware Bay for 5-6 generations) from both Long Island Sound and Delaware Bay, were compared in Delaware Bay in 1987. Inbred strains resembled their respective native stocks; both Long Island groups initiated gonadal development and spawning about one month earlier and spawned over a shorter duration than both Delaware Bay groups. Analysis of covariance revealed that the effect of time on gonadal development was statistically different $(P \leq 0.05)$ for all between-location group comparisons, but not for the two within-location comparisons. Thus, after six generations of inbreeding in Delaware Bay, Long Island oysters maintained their characteristic pattern of gonadal development and spawning, indicating the existence of genetically different environmental requirements for gonadal maturation between the two locations.
\end{abstract}

\section{Introduction}

Intraspecific variation in various aspects of reproduction has been noted for several species of marine bivalves, and can be either genetic or non-genetic (adaptive) in nature (see Sastry, 1979; Barber and Blake, 1991). The suggestion that there are genetically distinct populations or "races" of eastern oysters, Crassostrea virginica (Gmelin), was first made by Loosanoff and Engle (1942). Stauber (1950) concluded that there were three physiological races of oysters, based on differences in temperatures at which

Received 25 February 1991; accepted 24 May 1991.

Present address: AT\&T, 412 Mt. Kemble Ave., Morristown, New Jersey 07960 . spawning was initiated in Long Island, New Jersey, and Texas populations. Because transplant experiments were not conducted, the relative contribution of genetic versus non-genetic factors to the observed differences was not determined. Loosanoff and Nomejko (1951) and Loosanoff (1969) transplanted stocks from various locations along the eastern and Gulf coasts of the U.S. to Milford, Connecticut, and histologically compared gonadal development. Differences in the timing and extent of gonadal development and spawning between some of these stocks in the common environment suggested the existence of genetic differences in the environmental factors regulating gonadal maturation. The possibility of acclimatization after transfer to the new environment, however, was not precluded. As stated by Loosanoff (1969), the best way to separate the genetic and environmental aspects of oyster reproduction would be to use "successive generations of laboratory-reared oysters originating from parents of different geographical areas."

The oyster ( $C$. virginica) selective breeding program of the Rutgers University Shellfish Research Laboratory includes a variety of wild (imported) stocks and laboratoryreared strains that originated from several locations (Haskin and Ford, 1979; Ford and Haskin, 1987). Initial examination of some of these strains (originating from Long Island Sound, Delaware Bay, and James River, Virginia, stocks) indicated that after several generations of inbreeding and maintenance in Delaware Bay, the timing of specific reproductive events remained characteristic of the site of geographic origin (Ford et al., 1990). The object of the present study was to establish whether these observed differences are attributible to intraspecific genetic variation. This was accomplished by simultaneously 
comparing cycles of gonadal maturation and spawning in both wild stocks and inbred strains originating from two locations: Long Island Sound and Delaware Bay.

\section{Materials and Methods}

Native oysters from Long Island Sound (LIN), native oysters from Delaware Bay (DBN), a 6th generation, 1985 year class, inbred strain originally imported from Long Island Sound to Delaware Bay in 1964 (LII), and a 5th generation, 1985 year class, inbred strain originating from Delaware Bay (DBI) were obtained in March 1987. Because the endoparasite Haplosporidium nelsoni (MSX) alters gonad development and relative fecundity (Barber et al., 1988; Ford and Figueras, 1988), all oysters used in this study were first "purged" of MSX (Ford and Haskin, $1988 \mathrm{a}, \mathrm{b}$ ) by being suspended in wire trays from the laboratory dock (Bivalve, New Jersey) in the Maurice River (salinity < 5 ppt) for several weeks. On 1 May 1987, all experimental groups were moved to the tidal flats of lower Delaware Bay, Cape May County (salinity 18-24 ppt), for the remainder of the study.

Each group of oysters was sampled periodically between 17 March and 5 October 1987; ten individuals were shucked and fixed in Davidson's solution. A standard transverse (anterior) section across gill, stomach, intestine, and digestive diverticula was dehydrated, cleared, and embedded in paraplast. Six $-\mu \mathrm{m}$ sections were stained with iron hematoxylin, acid fuchsin, and aniline blue. Slides were examined for MSX prevalence (\% of sample infected) and intensity (Ford, 1985; Barber et al., 1988). Gonadal development was assessed from the histological sections using the Bioquant Image Analysis System (R\&M Biometrics, Inc., Nashville, Tennessee) to obtain a Gonadal Area Index, defined as the ratio of gonadal area to the entire visceral mass area $\times 100$. The gonadal area technique is a sensitive indicator of gametogenic events in oysters (Mori, 1979; Barber et al., 1988) and is more precise than measuring the thickness of the gonadal layer alone, as performed by Loosanoff and Nomejko (1951).

Cycles of gonadal development of the four groups of oysters, based on mean gonadal area indices, were compared using analysis of covariance after correcting for heteroscedasticity with the least squares method of White (1980). Analysis of covariance was accomplished using the dummy variable regression procedure of Wonnacott and Wonnacott (1970). Gonadal area index was regressed on a quadratic function of time (elapsed days from the date of the first sample) as:

Gonadal Area Index

$$
=\alpha_{\mathrm{i}} \text { Days }+\alpha_{\mathrm{j}} \mathrm{D}_{\mathrm{j}} \text { Days }+\beta_{\mathrm{i}} \text { Days }^{2}+\beta_{\mathrm{j}} \mathrm{D}_{\mathrm{j}} \text { Days }^{2},
$$

using the Tobit estimation to overcome the problem of zeros in the data set (Goldberger, 1964). The t statistic was then used to test the null hypothesis that $\alpha_{\mathrm{i}}=\alpha_{\mathrm{j}}$ and $\beta_{\mathrm{i}}=\beta_{\mathrm{j}}$, for each pair-wise group comparison. Conventional analysis of variance was not applied because of the presence of zero-valued observations, which invalidated the required normality assumption. Moreover, conventional analysis of variance compares only means, while the procedure used here allowed a global comparison.

Water temperature data from the experimental site were collected only sporadically during 1987 . Weekly averages of "calculated" daily water temperatures were therefore obtained from the regression of daily air temperatures (Cape May, New Jersey) on actual water temperatures collected at the experimental site from 1978-80 and 1985$88(\mathrm{n}=358 ; \mathrm{r}=0.77)$. These are presented in Figure 1 .

\section{Results}

The haplosporidan parasite $H$. nelsoni had little effect on gonadal development in any of the groups in this study. Prevalence and intensity of the parasite remained relatively low throughout the first four months of the study period because of the exposure of oysters to low salinity prior to initial sampling (Table I). Prevalence of $H$. nelsoni did not exceed $50 \%$ until $15 \mathrm{July}$, and systemic infections exceeded $50 \%$ only in the LIN group, after 15 July and the completion of spawning in that group. Gonadal development in $C$. virginica is most affected in individuals having systemic $H$. nelsoni infections (Barber et al., 1988; Ford and Figueras, 1988; Ford et al., 1990).

Cycles of gonadal maturation and spawning for the four groups of oysters are represented as mean gonadal area indices in Figure 2. Both Long Island groups (LIN and LII) initiated gonadal development in April and had maximal gonadal areas in late May (Figs. 2A, B). Some spawning occurred in both Long Island groups in late May and June, but greatest spawning activity occurred in July. Long Island oysters (both LIN and LII) were spent by August. Although some gonadal development was apparent in the DBI group in late April, most gonadal growth in both Delaware Bay groups (DBN and DBI) occurred in May (Figs. 2C, D). Maximal gonadal areas were found for both Delaware Bay groups in June, which was followed by a period (from June to August) of what appeared to be partial spawning and redevelopment. Final spawning and the cessation of gonadal activity in the Delaware Bay groups occurred in September. Thus there were similarities between inbred strains and native stocks within each site of origin but differences between sites of origin.

The null hypothesis of similarity of coefficients was rejected in all four pair-wise comparisons between strains having different geographic origins (Table II), indicating that the timing of gonadal growth and spawning of both native stocks and inbred strains from Delaware Bay were statistically different $(P \leq 0.05)$ from those of oysters (both 


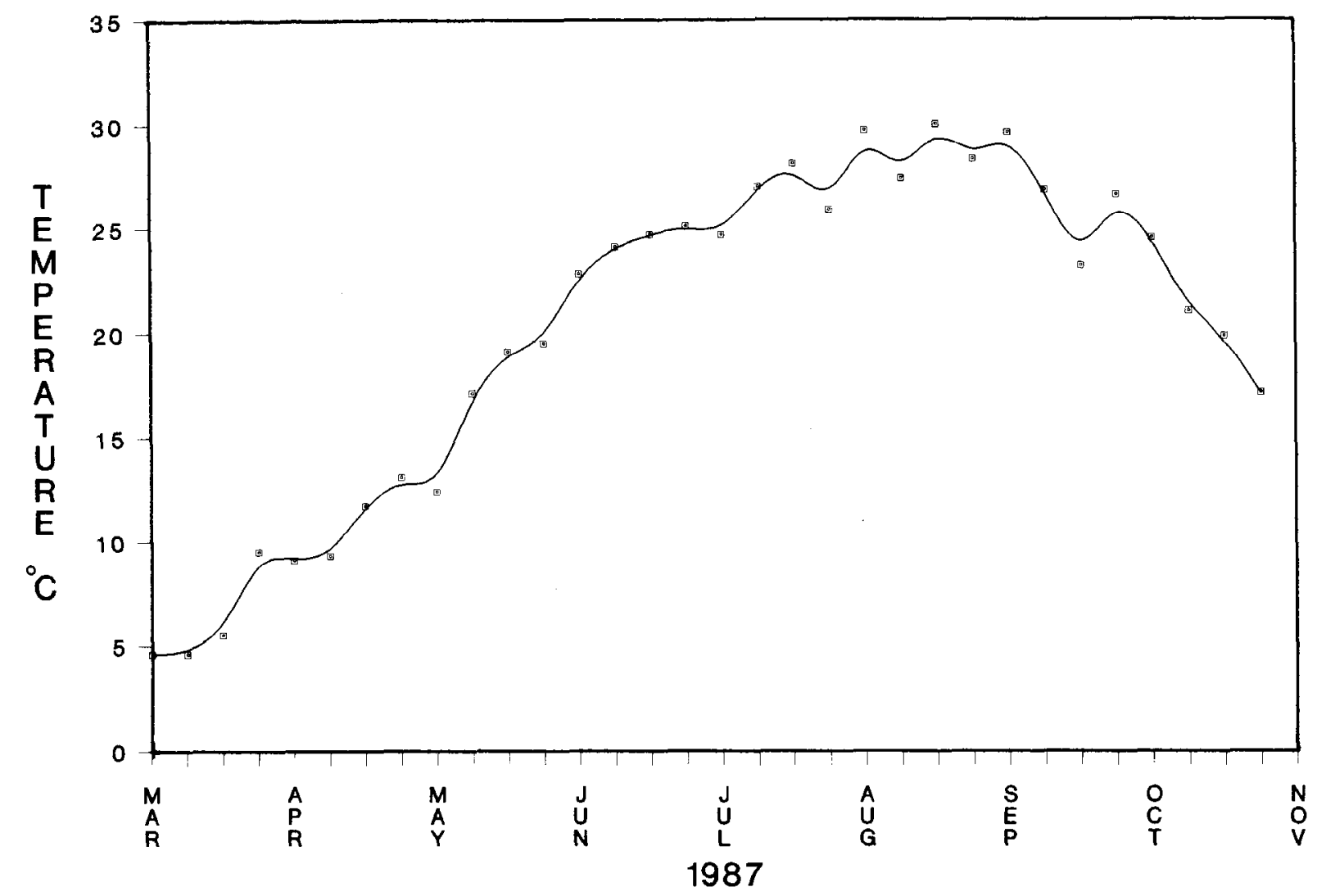

Figure 1. Weekly mean water temperature at the experimental site, lower Delaware Bay, as calculated from the regression of daily air temperature at Cape May, New Jersey, on water temperature readings from 1978 to 1980 and 1985 to 1988.

native and inbred) from Long Island Sound. On the other hand, the null hypothesis was accepted in the two comparisons involving inbred and native groups having the same site of origin (LIN-LII and DBN-DBI), indicating that the timing of gonadal maturation cycles was similar for native stocks and inbred strains within each site of origin.

\section{Discussion}

There were distinct differences in the timing of gonadal development and spawning of both native stocks and inbred strains between the Long Island and Delaware Bay sites of origin. Oysters in the Long Island groups initiated gonadal growth, achieved maximal gonadal development, and began spawning about one month earlier than oysters in the Delaware Bay groups. Additionally, both Delaware Bay groups exhibited a protracted period (about three months) of partial spawning and redevelopment. The statistical comparison of gonadal area indices reinforced the observations reported in this study and those of Ford $e t$ al. (1990). Time (elapsed days) had the same effect on gonadal area index for the LIN and LII groups and for the DBN and DBI groups, but not for any between-location comparison. Thus, the timing of gonadal development differed significantly between the Long Island and Delaware Bay locations. These differences were maintained in the Long Island inbred strain, even after six generations (23 years) in Delaware Bay, demonstrating that there are genetically determined differences in environmental criteria necessary for the initiation or completion of a particular gametogenic event at these two locations.

Several potential environmental regulators of bivalve reproduction have been identified, with the foremost of these being temperature (Sastry, 1979; Barber and Blake, 1991). Scallops (Argopecten irradians) from Woods Hole, Massachusetts, and Beaufort, North Carolina, acclimated to similar laboratory conditions prior to the initiation of gonadal development, exhibited maximal gonadal growth at 15 and $23^{\circ} \mathrm{C}$, respectively, indicating a non-adaptive (genetic) difference in temperature requirements for gonadal development between these two populations (Sastry, 1966). One of the original criteria upon which the determination of physiological races of oysters was based was the temperature at which spawning began. According to 
Table I

Prevalence $(P, \%)$ and intensity (I, expressed as \% systemic infections) of Haplosporidium nelsoni in experimental groups of oysters, Crassostrea virginica, on the various sampling dates

\begin{tabular}{lcccc}
\hline \hline Date (1987) & LIN & LII & DBN & DBI \\
$\% \mathrm{P} / \% \mathrm{I}$ & $\% \mathrm{P} / \% \mathrm{I}$ & $\% \mathrm{P} / \% \mathrm{I}$ & $\% \mathrm{P} / \% \mathrm{I}$ \\
\hline 17 March & - & $20 / 0$ & $50 / 20$ & $0 / 0$ \\
29 April & $0 / 0$ & $10 / 10$ & $20 / 0$ & $0 / 0$ \\
7 May & $0 / 0$ & $0 / 0$ & - & - \\
13 May & $0 / 0$ & $0 / 0$ & $0 / 0$ & $0 / 0$ \\
21 May & $0 / 0$ & $0 / 0$ & $0 / 0$ & $0 / 0$ \\
27 May & $0 / 0$ & $20 / 10$ & $0 / 0$ & $0 / 0$ \\
3 June & $0 / 0$ & $20 / 10$ & $20 / 10$ & $10 / 10$ \\
12 June & $0 / 0$ & $40 / 20$ & $40 / 10$ & $0 / 0$ \\
18 June & $0 / 0$ & $20 / 20$ & $20 / 20$ & $30 / 10$ \\
24 June & $40 / 10$ & $10 / 0$ & $40 / 20$ & $10 / 0$ \\
2 July & - & - & $20 / 0$ & $0 / 0$ \\
15 July & $90 / 0$ & $60 / 10$ & $50 / 0$ & $0 / 0$ \\
29 July & $100 / 60$ & $10 / 0$ & $60 / 20$ & $30 / 0$ \\
12 August & - & - & $70 / 20$ & $10 / 0$ \\
26 August & $90 / 70$ & $0 / 0$ & $40 / 0$ & $20 / 0$ \\
19 September & - & - & $40 / 30$ & $10 / 0$ \\
5 Octoher & $0 / 0$ & $10 / 0$ & $60 / 20$ & $40 / 30$ \\
\hline
\end{tabular}

LIN = Long Island Native.

LII $=$ Long Island Inbred.

DBN $=$ Delaware Bay Native.

$\mathrm{DBI}=$ Delaware Bay Inbred.

Stauber (1950), the Long Island Sound population was distinct because it began spawning when temperature reached $16.4^{\circ} \mathrm{C}$, while other populations spawned at higher temperatures. In this study, both Long Island groups began spawning when water temperature was between 15 and $20^{\circ} \mathrm{C}$, while spawning in the Delaware Bay groups began when water temperature was about $25-28^{\circ} \mathrm{C}$ (Fig. 1). Thus there is little difference in the temperature at which Long Island oysters spawn in their native setting or in Delaware Bay, even after six generations of inbreeding in Delaware Bay.

Gonadal development is an energy demanding process, with necessary nutrients coming either from stored reserves, recently ingested food, or both (Sastry, 1979; Barber and Blake, 1991). Site-specific variation in gonadal development of Mytilus edulis, A. irradians, and Placopecten magellanicus has been reported to be due to adaption (non-genetic) to local variations in environmental factors, most notably food availability (Newell et al., 1982; Bricelj et al., 1987; MacDonald and Thompson, 1988). The fact that at the same site in Delaware Bay, both inbred and native Long Island oysters have distinctly different gonadal cycles than Delaware Bay oysters, effectively eliminates food abundance as the sole regulator of gonadal development in $C$. virginica. Perhaps gonadal development in oysters is initiated in the presence of adequate food supplies, at a genetically determined temperature.
The results of this study and previous studies establish the existence of populations of $C$. virginica along the east coast of the United States that are genetically distinct based on differences in the timing of cycles of gonadal development and spawning. These intraspecific differences occur between populations located north and south of Long Island, New York. Loosanoff and Nomejko (1951) found that oysters from Massachusetts and Long Island Sound spawned successfully in Milford, Connecticut, while oysters from New Jersey and Virginia did not spawn or only partially spawned. Similarly, Loosanoff (1969) saw a difference in the temperature at which gonadal development was initiated between oysters from north of Long Island and south of Long Island. Oysters transplanted from Chesapeake Bay (Maryland) to Florida conformed to local spawning conditions after one year (Butler, 1955), indicating that observed differences in spawning temperatures between these locations were non-genetic.

Genetic discontinuities along the distributional range of $C$. virginica have been reported at Brownsville, Texas, based on electrophoretic variation in proteins encoded by nuclear genes (Buroker, 1983) and along the mid-Atlantic coast of Florida based on restriction site variation in mitochondrial DNA (Reeb and Avise, 1990). It is noteworthy that populations of oysters exist that have genetically distinct gonadal maturation cycles and yet are indistinguishable based on both allozyme frequencies and mtDNA restriction site variation. The fact that discrepancies exist between allozyme frequencies, mtDNA patterns, and physiological processes such as reproduction, point out that there is no simple means of delineating genetic boundaries among oyster populations (see review by Gaffney, 1991).

The existence of stocks of oysters having genetically distinct reproductive cycles has implications for the oyster fishery. Oysters transplanted from a northern location (north of Long Island) to a southern location (south of Long Island), requiring lower temperatures to initiate gonadal development, would spawn earlier than the local population. In the case of Long Island oysters in Delaware Bay, there is a potential one month overlap in spawning periods during which inter-breeding could occur. For the most part, however, the spawning periods would remain distinct. Oysters transplanted from southern to northern locations might not experience temperatures high enough to initiate gonadal devclopment or spawning. In this case, oysters with unspawned or partially spawned and resorbing gametes would have little reproductive value and would be of poorer quality and lower commercial value. Hatchery production of oysters would be enhanced by the ability to obtain naturally conditioned broodstock over a wider time interval than what is available with local stocks alone. 
$A$

LONG ISLAND NATIVE

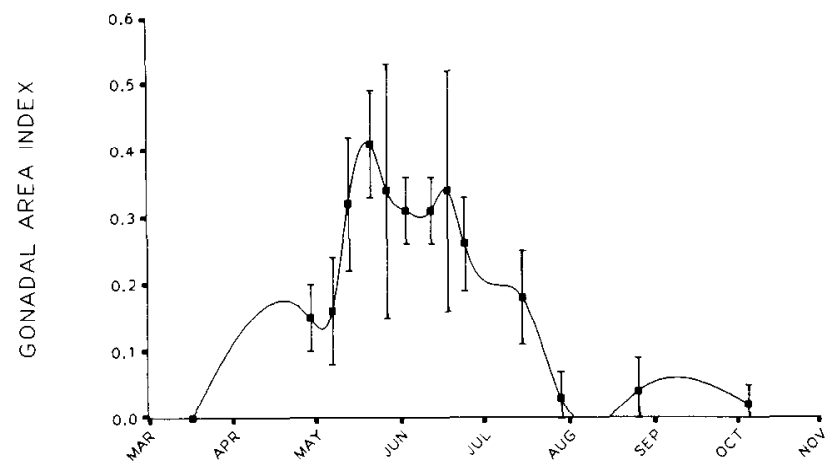

C DELAWARE BAY NATIVE

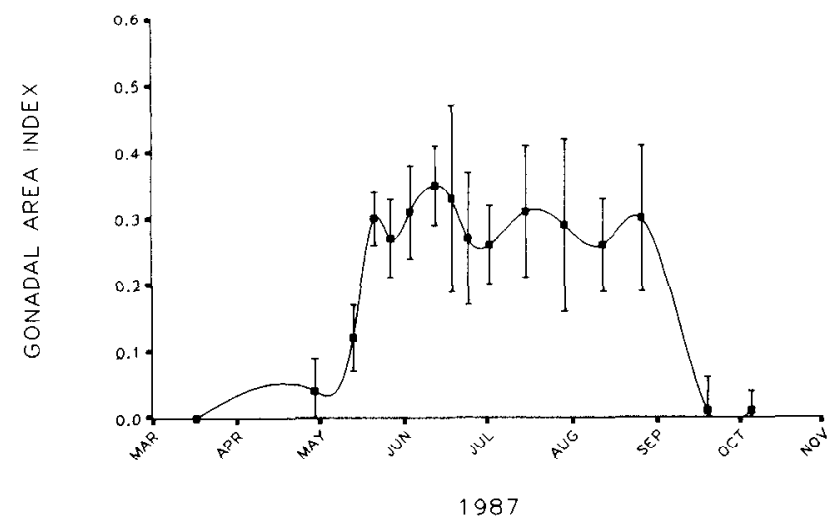

$B \quad$ LONG ISLAND INBRED

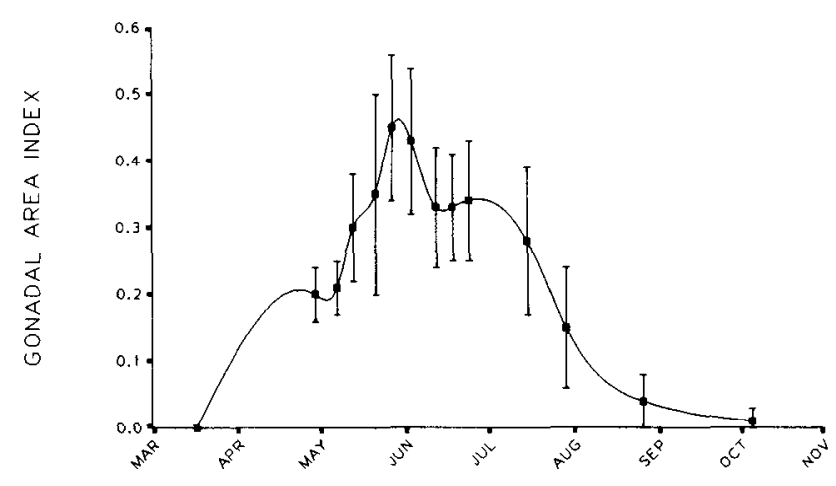

D DELAWARE BAY INBRED

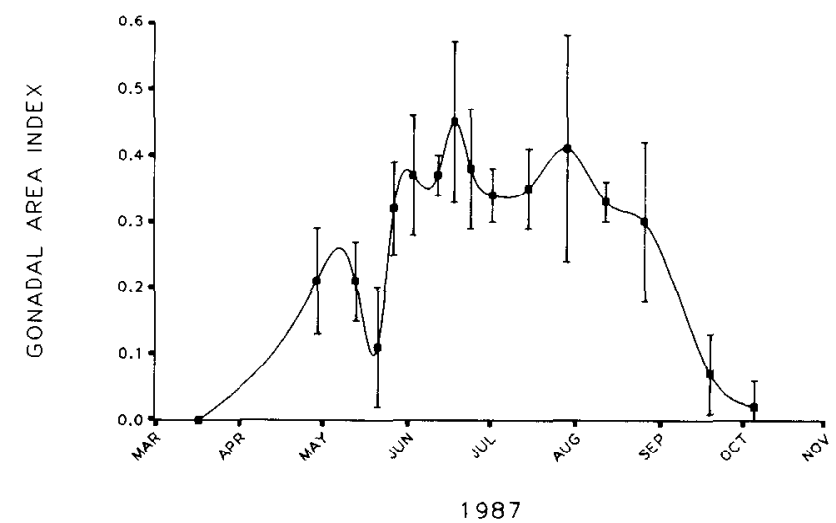

Figure 2. Mean gonadal area index ( $\pm 1 \mathrm{SD}$ ) for four groups of Crassostrea virginica: $\mathrm{A}=$ Long Island Native (LIN); B = Long Island Inbred (LII); C = Delaware Bay Native (DBN); D = Delaware Bay Inbred (DBI). Fitted lines are spline interpolations.

\section{Table II}

Statistical comparison ( $t$-test) of coefficients $\alpha$ and $\beta$ from the quadratic model for cach possible combination of oyster, Crassostrea virginica, groups $H_{\mathrm{o}}: \alpha_{\mathrm{i}}=\alpha_{\mathrm{j}}$ and $\beta_{\mathrm{i}}=\beta_{\mathrm{j}}$, where $i$ and $j$ are different groups of oysters

\begin{tabular}{cccc}
\hline \hline $\begin{array}{c}\text { Groups } \\
\mathrm{i} \quad \mathrm{j}\end{array}$ & $\begin{array}{c}\mathrm{t} \\
\left(\alpha_{\mathrm{i}}=\alpha_{\mathrm{j}}\right)\end{array}$ & $\begin{array}{c}\mathrm{t} \\
\left(\beta_{\mathrm{i}}=\beta_{\mathrm{j}}\right)\end{array}$ & $P^{*}$ \\
\hline LIN-DBN & 6.17 & 7.72 & $P \leq 0.002$ \\
LIN-LII & 1.39 & 0.44 & \\
LIN-DBI & 4.01 & 6.33 & $P \leq 0.02$ \\
DBN-LII & 5.50 & 6.66 & $P \leq 0.005$ \\
DBN-DBI & 2.62 & 1.59 & \\
LII-DBI & 2.89 & 4.36 & $P \leq 0.05$ \\
\hline
\end{tabular}

* If comparisons of both $\alpha$ and $\beta$ are rejected.

LIN - Long Island Native.

LII = Long Island Inbred.

$\mathrm{DBN}=$ Delaware Bay Native.

DBI = Delaware Bay Inbred.

\section{Acknowledgments}

We thank J. Kirkley for generous assistance with the statistical analysis and D. O'Connor and R. Barber for histological preparation and disease analysis. Comments by R. Mann, J. Graves, and P. Gaffney improved the manuscript. This work is the result of research sponsored by NOAA, Office of Sea Grant, Department of Commerce, under grant No. NA89AA-D-SG057 (Project No. R/F-23). The U.S. Government is authorized to produce and distribute reprints for governmental purpose notwithstanding any copyright notation that may appear hereon. This is New Jersey Sea Grant Publication No. NJSG-90-238 and New Jersey Agricultural Experiment Station Publication No. D 32405-3-90, supported by state funds. This is contribution No. 1673 from the Virginia Institute of Marine Science, College of William and Mary, and No. 91-22 from the Institute of Marine and Coastal Sciences, Rutgers University. 


\section{Literature Cited}

Barber, B. J., S. E. Ford, and H. H. Haskin. 1988. Effects of the parasite MSX (Haplosporidium nelsoni) on oyster (Crassostrea virginica) energy metabolism. I. Condition index and relative fecundity. J. Shellfish Res. 7: 25-31.

Barber, B. J., and N. J. Blake. 1991. Reproductive physiology. Pp. 377-428 in Scallops: Biology, Ecology and Aquaculture, S. Shumway, ed. Elsevier Science Publishers B. V., Amsterdam.

Bricelj, V. M., J. Epp, and R. E. Malouf. 1987. Intraspecific variation in reproductive and somatic growth cycles of bay scallops Argopecten irradians. Mar. Ecol. Prog. Ser. 36: 123-137.

Buroker, N. E. 1983. Population genetics of the American oyster Crassostrea virginica along the Atlantic coast and the Gulf of Mexico. Mar. Biol. 75: 99-112.

Butler, P. A. 1955. Reproductive cycle in native and transplanted oysters. Proc. Natl. Shellfish Assoc. 46: 75.

Ford, S. E. 1985. Chronic infections of Haplosporidium nelsoni (MSX) in the oyster Crassostrea virginica. J. Invertebr. Pathol. 45: 94-107.

Ford, S. E., and A. J. Figueras. 1988. Effects of sublethal infection by the parasite Haplosporidium nelsoni (MSX) on gametogenesis, spawning, and sex ratios of oysters in Delaware Bay, USA. Diseases Aquat. Org. 4: 121-133.

Ford, S. E., and H. H. Haskin. 1987. Infection and mortality patterns in strains of oysters Crassostrea virginica selected for resistance to the parasite Haplosporidium nelsoni (MSX). 376.

Ford, S. E., and H. H. Haskin. 1988a. Management strategies for MSX (Haplosporidium nelsoni) disease in Eastern oysters. Am. Fish. Soc. Spec. Publ. 18: 249-256.

Ford, S. E., and H. H. Haskin. 1988b. Comparison of in vitro salinity tolerance of the oyster parasite Haplosporidiurn nelsoni (MSX) and hemocytes from the host, Crassostrea virginica. Comp. Biochem. Physiol. 90A: 183-187.

Ford, S. E., A. J. Figueras, and H. H. Haskin. 1990. Influence of selective breeding, geographic origin, and disease on gametogenesis and sex ratios of oysters, Crassostrea virginica, exposed to the parasite Haplosporidium nelsoni (MSX). Aquaculture 87: 285-301.

Gaffney, P. M. 1991. Biochemical and population genetics. In Biology. Culture and Management of the American Oyster, V. L. Kennedy,
A. F. Eble, and A. Rosenfield, eds. Maryland Sea Grant, College Park. In Press.

Goldberger, A. S. 1964. Econometric Theory. John Wiley and Sons, Inc., New York.

Haskin, H. H., and S. E. Ford. 1979. Development of resistance to Minchinia nelsoni (MSX) mortality in laboratory-reared and native oyster stocks in Delaware Bay. Mar. Fish. Rev. 41: 54-63.

Loosanoff, V. L. 1969. Maturation of gonads of oysters, Crassostrea virginica, of different geographical areas subjected to relatively low temperatures. Veliger 11: 153-163.

Loosanoff, V. L., and J. B. Engle. 1942. Accumulation and discharge of spawn by oysters living at different depths. Bid Bull. 82: 413422.

Loosanoff, V. L., and C. A. Nomejko. 1951. Existence of physiologicallydifferent races of oysters, Crassostrea virginica. Biol. Bull. 101: 151156.

MacDonald, B. A., and R. J. Thompson. 1988. Intraspecific variation in growth and reproduction in latitudinally differentiated populations of the giant scallop Placopecten magellanicus (Gmelin). Dit Dotl. 175: $361-371$.

Mori, K. 1979. Effects of artificial eutrophication on the metabolism of the Japanese oyster Crassostrea gigas. Mar. Biol. 53: 361-369.

Newell, R. I. E., T. J. Hilbish, R. K. Koehn, and C. J. Newell. 1982. Temporal variation in the reproductive cycle of Mytilus edulis L. (Bivalvia, Mytilidae) from localities on the east coast of the United Stot. 162: 299-310.

Reeb, C. A., and J. C. Avise. 1990. A genetic discontinuity in a continuously distributed species: mitochondrial DNA in the American oyster, Crassostrea virginica. Gentics 124: 397-406.

Sastry, A. N. 1966. Variation in reproduction of latitudinally separated populations of two marine invertebrates. Am. Zool. 6: 149.

Sastry, A. N. 1979. Pelecypoda (excluding Ostreidae). Pp. 113-292 in Reproduction of Marine Invertebrates, Vol, V, A. C. Giese and J. S. Pearse, eds. Academic Press, New York.

Stauber, I. A. 1950. The problem of physiological species with special reference to oysters and oyster drills. Ecology 31: 109-118.

White, H. 1980. A heteroskedasticity-consistent covariance-matrix estimator and a direct test for heteroskedasticity. Econometrica 48: 817-838.

Wonnacott, R. J., and T. H. Wonnacott. 1970. Econometrics. John Wiley and Sons, Inc., New York. 